\title{
Sistem Monitoring Perilaku Pengendara Mobil Berbasis Internet of Things
}

\author{
Andri Ulus Rahayu \\ Universitas Siliwangi, Jl. Siliwangi No. 24, Tasikmalaya, 46115, Indonesia
}

\section{ARTICLE INFORMATION}

Received: January $22^{\text {nd }}, 2021$

Revised: February $15^{\text {th }}, 2021$

Available online: March $31^{\text {st }}, 2021$

\section{KEYWORDS}

Driving Behavior, IoT, OBD II, Raspberry Pi

\section{CORRESPONDENCE}

Phone: 081288883489

E-mail: andriulusr@unsil.ac.id

\section{A B S T R A C T}

This research is created as a system for a car rental service. The system has monitoring features allowing the car rental owner to monitor the engine condition. The monitoring is performed by using a web interface that could read data from OBD-II that sent by raspberry pi 2 . The owner can also monitor the position of the car by using coordinates sent from a smartphone by utilizing the GPS feature. In addition, it also has a reporting feature that allows the owner to track the data history from OBD II about the engine rpm, speed, engine load \& temperature. Moreover, the owners can identify the route that has been passed by their car. Likewise, this system provides a program that analyzes the car driver's behavior based on the determined rules. The analysis was conducted based on all data from OBD-II in the database server and all data of driving rules violation performed by the driver. The result is an assessment of the driver as a driving error rate. This study generated 173 data of which 9 were driving rules violations with a $5.20 \%$ driving error rate. The report can be obtained by selecting the time interval. It also downloadable and can be sent by email.

\section{PENDAHULUAN}

Perilaku mengemudi seseorang sangat berpengaruh terhadap probabilitas terjadinya kecelakaan. Salah satu faktor penyebab terjadinya kecelakaan adalah kecepatan. Berdasarkan beberapa penelitian sebelumnya [1],[2],[3], dijelaskan bahwa tingkat resiko kecelakaan berhubungan dengan tingkat kecepatan saat berkendara.

Tingkat resiko kecelakaan akan meningkat lebih tinggi ketika kecepatan meningkat dan sebaliknya. Selain itu, perilaku mengemudi juga dapat mempengaruhi ketahanan dari mesin mobil itu sendiri. Oleh karena itu diperlukan suatu metode yang dapat digunakan untuk menganalisis perilaku pengendara mobil berdasarkan indikator pembacaan sensor-sensor pada mobil.

Dengan memanfaatkan metode IOT (Internet of Things) sebagai metode komunkasi data dan OBD II (On board Diagnostic II) sebagai alat pembaca data mesin mobil [9], maka memungkinkan untuk menciptakan suatu sistem yang dapat melakukan monitoring dengan menggunakan raspberry pi [10]. Selain itu juga dimungkinkan untuk menciptakan sistem reporting perilaku pengendara mobil rental berdasarkan data yang dikirim langsung dari mobil itu sendiri.

Internet of things adalah sebuah teknologi yang memungkinkan kita untuk menghubungkan mesin, peralatan, dan benda fisik lainnya dengan sensor jaringan dan aktuator untuk memperoleh data dan mengelola kinerjanya sendiri, sehingga memungkinkan mesin untuk berkolaborasi dan bahkan bertindak berdasarkan informasi baru yang diperoleh secara independen [4].

Pada penelitian ini akan dibuat sebuah sistem berbasis IoT pada sebuah mobil rental. Tujuan utama dari sistem ini adalah untuk melakukan monitoring dan membuat laporan terhadap setiap pengemudi mobil rental. Sehingga nantinya pemilik rental dapat melakukan penyaringan terhadap calon penyewa mobil berdasarkan hasil dari analisis perilaku pengemudi dari laporan tersebut. Perilaku yang dimaksud bukanlah perilaku terhadap lingkungan melainkan perilaku terhadap mobil yang ia kendarai berdasarkan hasil pembacaan data dari OBD II. Selain itu, berdasarkan hasil wawancara terhadap sampel rental mobil yang ada di Bandung, dibutuhkan pula suatu program yang dapat mengetahui posisi mobil yang sedang disewakan.

OBD atau On Board Diagnostic adalah istilah yang digunakan dunia otomotif yang mengacu pada kemampuan kendaraan untuk melakukan diagnosis mandiri. OBD II mulai diperkenalkan dalam dunia industri otomotif dan diterapkan pada kendaraan yang di produksi mulai tahun 1996, setelah sebelumnya standar ini di kenal dengan nama ALDL (Assembly Line Diagnostic Link) kemudian berkembang menjadi OBD atau menjadi OBD I setelah OBD II diperkenalkan [5].

Data yang diterima dari OBD II adalah berupa data heksa. Data heksa dari OBD II diubah menjadi integer. Semua fungsi menggunakan rumus standarisasi pembacaan OBD II (SAE J1979) [5]. Semua data dari OBD II akan diterjemahkan oleh program di raspberry. 
Ada 3 bagian terpenting dalam pembuatan sistem ini yaitu: (1) Pengambilan dan pengiriman data OBD II oleh raspberry ke server basis data. (2) Pengolahan basis data. (3) Proses monitoring.

\section{METODE}

Penelitian ini menggunakan metode eksperimental dimana sistem dirancang dan implementasikan langsung kepada sebuah mobil. Sistem yang dibuat adalah berupa sistem monitoring dan reporting perilaku pengemudi mobil

\section{Cara Kerja Sistem}

Pemilik rental mobil biasanya tidak mengetahui perilaku mengemudi setiap penguna jasa rental yang menyewa mobilnya. Untuk itu, akan lebih baik jika setiap mobil yang disewakan dapat memberikan laporan tentang bagaimana perilaku mengemudi dari pengguna jasa rental tersebut.

Jika implementasi dari perancangan berhasil dilakukan, sistem akan memiliki spesifikasi sebagai berikut.

- Mampu menampilkan data lokasi dan data mesin real-time atau data yang paling akhir.

- Mampu memberikan laporan secara keseluruhan beserta analisis rata-rata dan nilai tertinggi dari keempat komponen yaitu nilai rpm, kecepatan, engine load dan temperatur mesin.

- Mampu menampilkan data pelanggaran dari pengemudi terhadap aturan yang sudah ditentukan sebelumnya yang akan dijadikan penilaian untuk perilaku pengemudi berdasarkan tingkat kesalahan dalam mengemudi.

- Mampu mencetak keseluruhan data dengan format pdf dan mampu mengirimkan keseluruhan data melalui e-mail.

Implementasi dilakukan pada sebuah mobil yang mendukung terhadap protocol yang dimiliki oleh OBD II. Dengan menggunakan sistem ini diharapkan pemilik rental mobil dapat melakukan monitoring secara langsung untuk mengetahui data mesin secara real-time atau data terakhir dan posisi mobil secara real-time atau posisi teakhir. Selain itu pemilik rental juga dapat mengunduh laporan mengenai kondisi mesin saat pemakaian secara keseluruhan melalui antarmuka web yang telah disediakan. Data dapat diunduh berdasarkan interval waktu per jam atau per hari. Setelah sistem dibuat maka akan dilakukan pengujian lapangan untuk menetahui apakah sistem sudah berjalan dengan baik atau tidak.

Adapun aturan yang harus dipatuhi oleh pengendara mobil yaitu [7],[8]:

- Batas maksimum putaran mesin adalah $2.500 \mathrm{rpm}$.

- Kecepatan maksimum yang diperbolehkan adalah 80 km/jam.

- Temperatur mesin maksimum 90 derajat celcius.

- Batas maksimum nilai engine load adalah $80 \%$.

Keempat aturan diatas akan menetukan penilaian dari perilaku pengemudi mobil rental. Penentuan nilai ini dilakukan oleh program khusus yang bertugas menghitung berapa banyak pelanggaran terjadi. Semakin banyak pelanggaran maka semakin buruk nilai yang didapat penyewa mobil. Untuk menentukan nilai dari pengemudi akan dilakukan analisis terhadap data keseluruhan yang nantinya akan menghasilkan tingkat kesalahan berkendara dengan menggunakan rumus seperti yang ditunjukan oleh persamaan (1).
Error rate driving $=\frac{\text { Jumlah pelanggaran }}{\text { Jumlah data yang masuk }} \times 100 \%$

\section{Desain Sistem dan Implementasi}

Cara kerja sistem secara umum dapat dilihat pada Gbr. 1 Sistem terdiri atas blok pengambilan data dan blok pengolahan data.

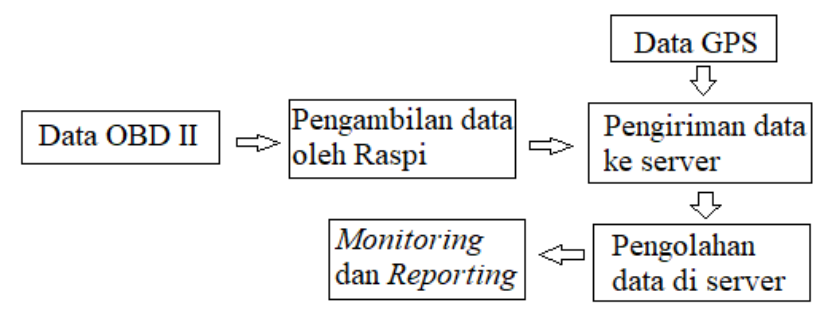

Gbr. 1 Blok diagram sistem keseluruhan

Sistem yang dibangun memungkinkan pemilik rental untuk dapat melakukan monitoring berdasarkan data yang masuk ke server basis data dapat diakses melalui antarmuka web. Selain itu pemilik rental juga bisa mendapatkan report dari hasil pencetakan data keseluruhan yang berupa history data mesin dari $O B D$ II beserta analisis data dan data lokasi dari GPS. Dengan GPS system dapat mendeteksi setiap perubahan posisi yang terjadi [11]. Cara kerja sistem dapat dilihat pada Gbr. 2.

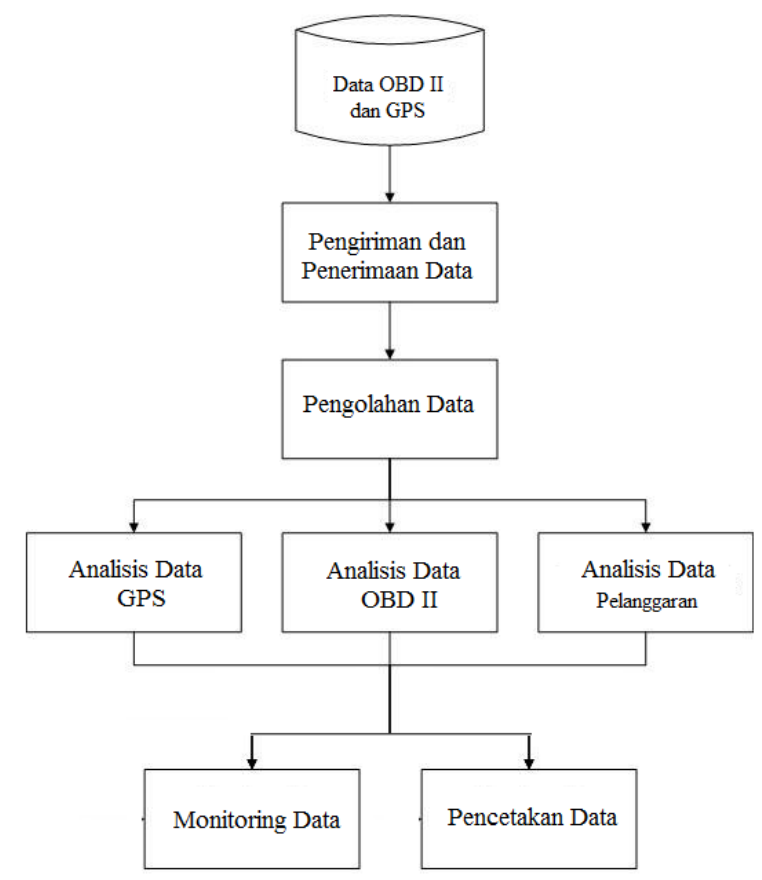

Gbr. 2 Cara kerja sistem secara keseluruhan

Sistem bekerja dengan melakukan pengolahan data dari $O B D I I$ dan data GPS dari Data $O B D I I$ dan GPS dikirim ke server basis data oleh raspberry dan ponsel cerdas. Data yang sudah ada di basis data akan diolah untuk kemudian dianlaisis dan ditampilkan di halaman web. Selain itu data yang sudah dianalisis juga dapat diunduh dan dikirim ke email dalam file berformat pdf. Analisis data yang dilakukan adalah analisis data pelanggaran yang dilakukan oleh pengemudi.

Ada 4 buah data dari $O B D I I$ yang dibutuhkan untuk sistem ini yaitu putaran mesin, kecepatan, temperatur dan engine load. Untuk mengambil keempat data tersebut maka dibuatlah 4 buah program pada raspberry pi.

Yang pertama adalah program yang berfungsi untuk melakukan pemindaian port bluetooth yang tersedia (telah terkoneksi dengan 
bluetooth raspberry) dan mengembalikan nama serial Bluetooth sesuai dengan portnya.

Yang kedua adalah program yang berfungsi untuk menerjemahkan data berupa heksa yang diterima dari $O B D$ II menjadi nilai suatu parameter yang dapat dimengerti. Sebelum diterjemahkan, data heksa dari $O B D$ II diubah menjadi integer. Semua fungsi menggunakan rumus standarisasi pembacaan $O B D$ II (SAE J1979) [6].

Yang ketiga adalah program yang berfungsi untuk mengatur alur komunikasi dengan perangkat $O B D$ II. Selain itu, program tersebut juga menginisialisasi port dengan cara mengatur kembali koneksi dengan perangkat $O B D I I$, serta memperoleh $P I D$ yang tersedia pada mobil tersebut.

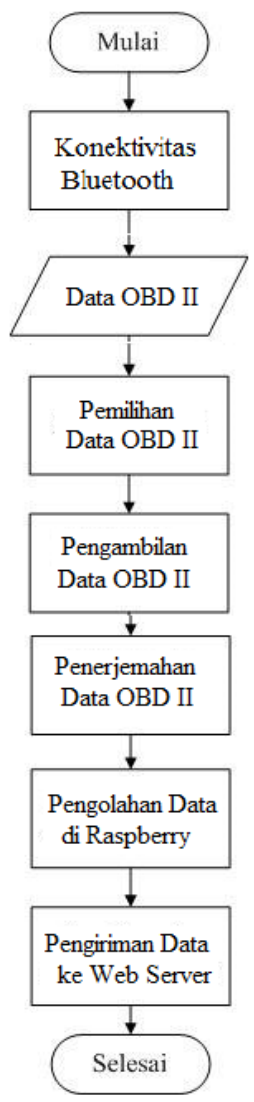

Gbr. 3 Alur proses pengambilan dan pengiriman data $O B D I I$

Terakhir adalah program utama yang melakukan pemanggilan ke program-program yang telah dibuat tadi. Program tersebut berfungsi untuk melakukan pencatatan data dari parameterparameter yang terdaftar untuk kemudian mengirimkannya ke server basis data. Gbr 3 memperlihatkan tahapan dari proses pemilihan dan penerjemahan data OBD II hingga pengirimannya ke server basis data.

Setelah data OBD II dikirim ke basis data server, data yang ada kemudian diolah oleh beberapa program web. Prrogram utama yang dibuat adalah program monitoring, program pencetakan data OBD II dan rute perjalanan dan terakhir program pengolah data pelanggaran.

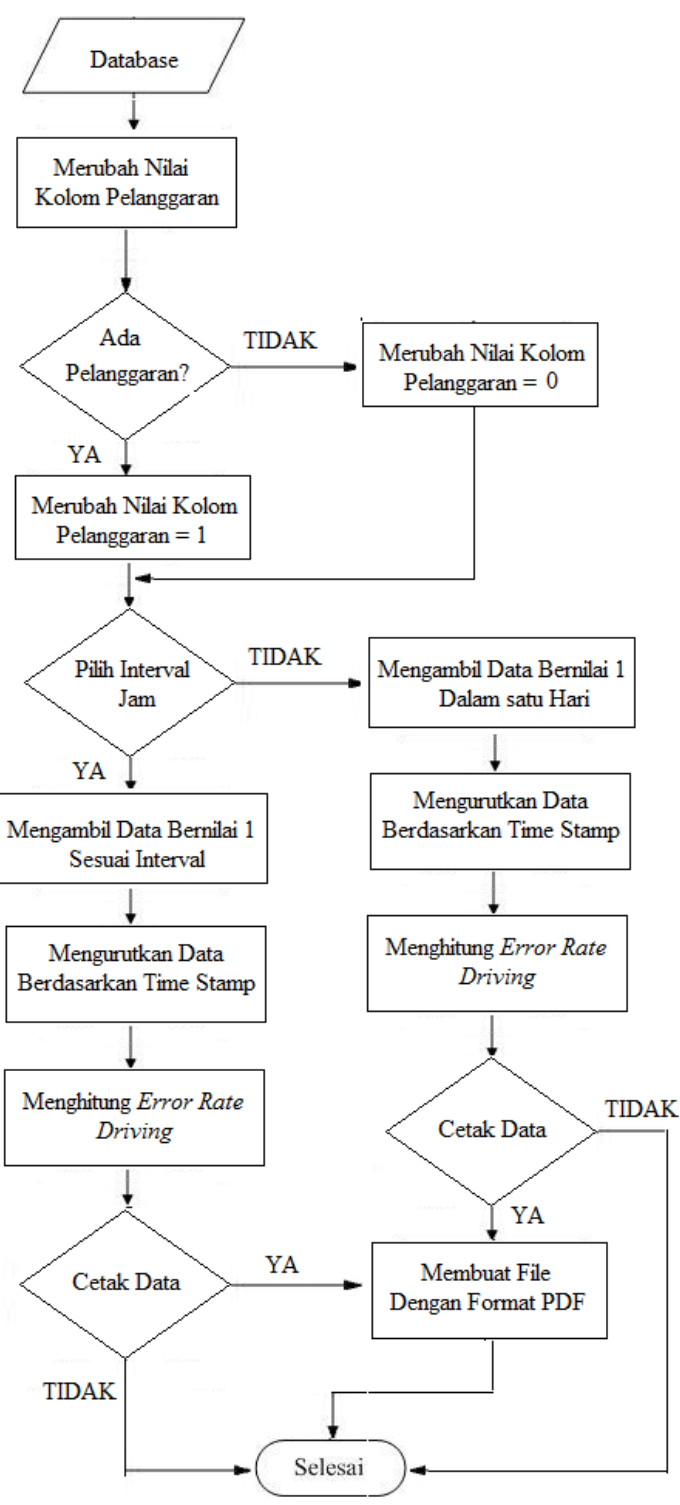

Gbr. 4 Alur proses pengolahan data pelanggaran

Gbr. 4 merupakan alur dari proses pengolahan data pelanggaran. Data pelanggaran adalah semua data yang melanggar aturan yang telah ditentukan. Banyaknya data pelanggaran nantinya akan menentukan tingkat kesalahan mengemudi yang dihasilkan.

\section{HASIL DAN PEMBAHASAN}

Pada uji coba ini akan dilakukan beberapa perlakuan terhadap mobil yang akan digunakan yaitu berupa perlakuan yang bersifat melanggar aturan yang sudah dibuat. Hal ini dilakukan untuk mengetahui apakah sistem berjalan dengan baik atau tidak.

\section{Pengujian Program Monitoring Data}

Pengujian dilakukan pada tanggal 18 Agustus 2016 di daerah Lembang. Hasilnya dapat dilihat pada Tabel I dan Gbr. 6 . 
Tabel I

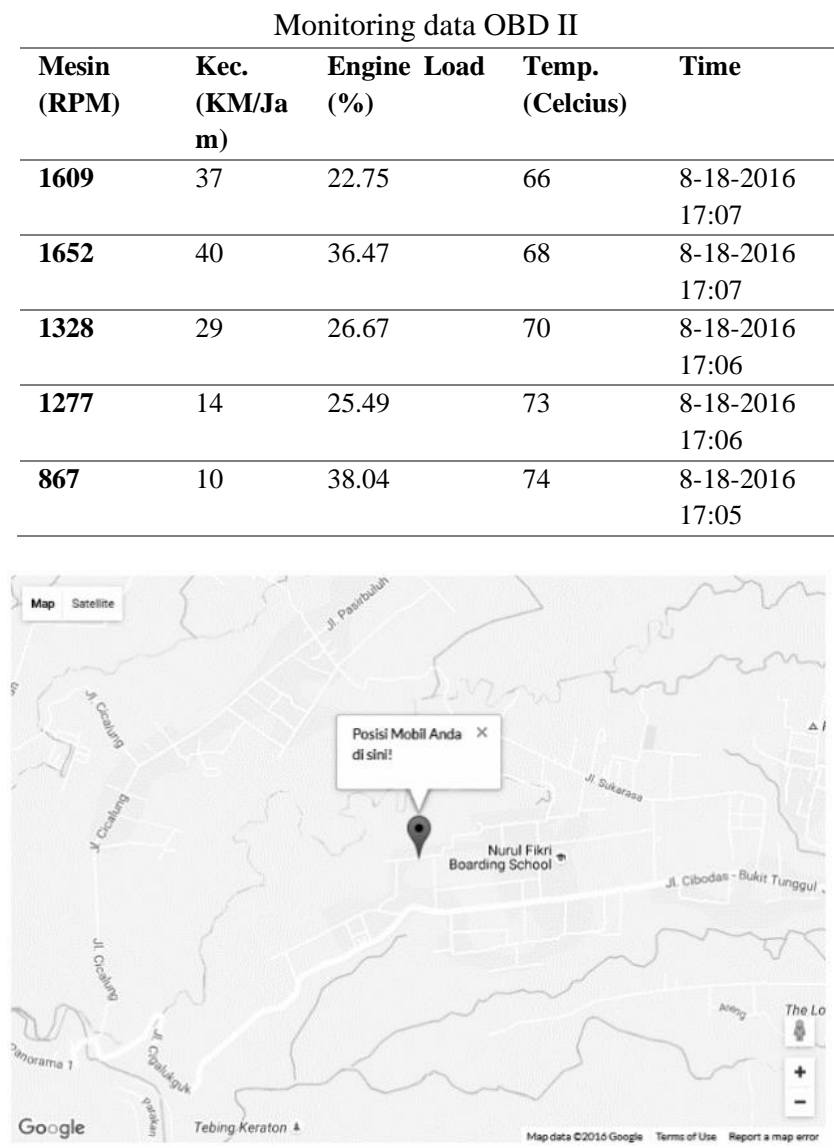

Gbr. 5 Monitoring data lokasi

Dari hasil pengujian dapat dilihat bahwa program monitoring berjalan dengan baik dan mampu menampilkan data OBD II terakhir dan data lokasi terakhir. Data OBD II maupun data lokasi berhasil melakukan update sesuai interval waktu yang telah ditentukan.

\section{Pengujian Program Reporting Data}

Selanjutnya akan dilakukan pengujian terhadap program reporting data. Pengujian dilakukan pada tanggal 11 Agustus 2016.

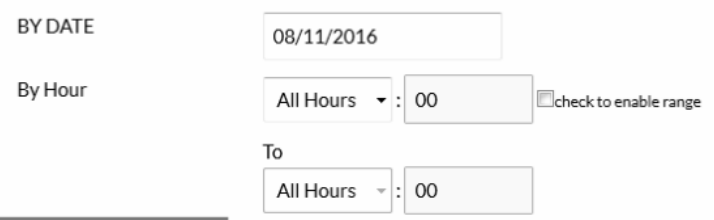

SHOW REPORT

Gbr. 6 Tampilan pemilihan interval waktu

Gbr. 6 menunjukan tampilan pemilihan interval waktu untuk laporan. Pengujian dapat dilakukan dengan melakukan pengujian laporan berdasarkan pemilihan interval jam dan pengujian laporan harian. Hasil dari pengujian tersebut adalah sebagai berikut.

\section{Pengujian berdasarkan interval jam.}

Pengujian dilakukan pada interval 17.00 sampai 17.59. hasil dari pengujian tersebut adalah sebagai berikut.

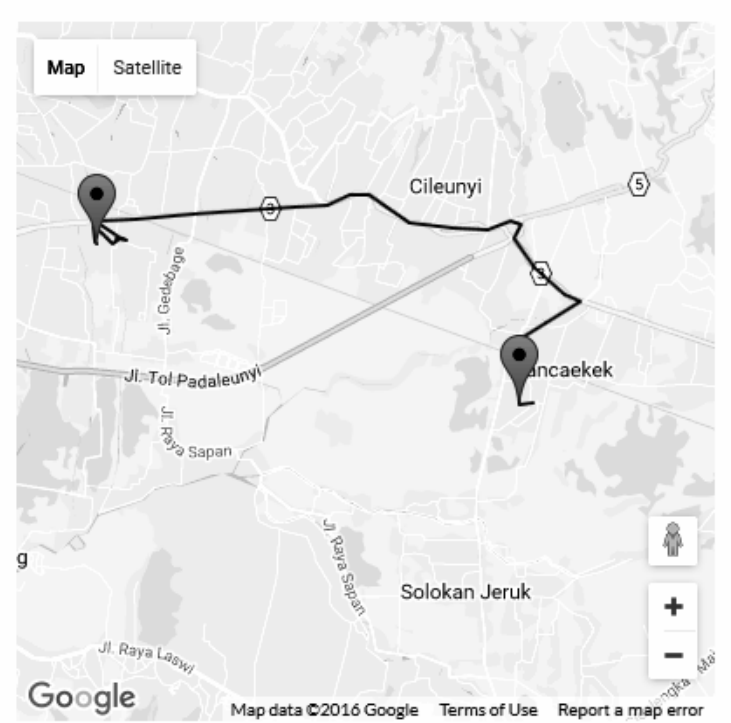

Gbr. 7 Report data lokasi per interval waktu

Gbr. 7 menunjukan history rute yang diambil oleh mobil. Penanda menunjukan posisi awal dan akhir dari mobil pada interval waktu tersebut.

Tabel II

Report data OBD II per interval waktu

\begin{tabular}{|c|c|c|c|c|c|}
\hline $\begin{array}{l}\text { Mesin } \\
(\text { rpm) }\end{array}$ & $\begin{array}{l}\text { Kec. } \\
\text { (KM/Jam } \\
\text { ) }\end{array}$ & $\begin{array}{l}\text { Engine } \\
\text { Load } \\
(\%)\end{array}$ & $\begin{array}{l}\text { Temp. } \\
\text { (Celcius } \\
\text { ) }\end{array}$ & Date & Time \\
\hline 1921 & 21 & 35.29 & 77 & $\begin{array}{l}\text { 11-Aug- } \\
2016\end{array}$ & $17: 37$ \\
\hline 718 & 0 & 44.71 & 78 & $\begin{array}{l}\text { 11-Aug- } \\
2016\end{array}$ & $17: 38$ \\
\hline 1078 & 5 & 36.47 & 78 & $\begin{array}{l}\text { 11-Aug- } \\
2016\end{array}$ & $17: 38$ \\
\hline 1441 & 15 & 51.76 & 78 & $\begin{array}{l}\text { 11-Aug- } \\
2016\end{array}$ & $17: 39$ \\
\hline 1332 & 7 & 64.31 & 78 & $\begin{array}{l}\text { 11-Aug- } \\
2016\end{array}$ & $17: 39$ \\
\hline 1769 & 27 & 67.84 & 79 & $\begin{array}{l}\text { 11-Aug- } \\
2016\end{array}$ & $17: 40$ \\
\hline 2066 & 23 & 38.43 & 79 & $\begin{array}{l}\text { 11-Aug- } \\
2016\end{array}$ & $17: 41$ \\
\hline 1769 & 27 & 47.84 & 78 & $\begin{array}{l}\text { 11-Aug- } \\
2016\end{array}$ & $17: 41$ \\
\hline ... & $\cdots$ & $\ldots$ & $\ldots$ & $\ldots$ & $\cdots$ \\
\hline 1488 & 36 & 86.67 & 80 & $\begin{array}{l}\text { 11-Aug- } \\
2016\end{array}$ & $17: 59$ \\
\hline
\end{tabular}


Tabel III

Analisis data OBD II per interval waktu

\begin{tabular}{lllll}
\hline & $\begin{array}{l}\text { Mesin } \\
(\text { RPM) }\end{array}$ & $\begin{array}{l}\text { Kecepatan } \\
(\text { KM/Jam) }\end{array}$ & $\begin{array}{l}\text { Engine } \\
\text { Load } \\
(\%)\end{array}$ & $\begin{array}{l}\text { Temp. } \\
\text { (Celcius) }\end{array}$ \\
\hline Nilai Tertinggi & 2453 & 67 & 65.88 & 82 \\
\hline Nilai Rata-Rata & 1378.11 & 21.82 & 40.3 & 74.86
\end{tabular}

Tabel III menunjukan history data OBD II yang ada di basis data sesuai interval yang telah dipilih. Diakhir halaman ini terdapat analisis berupa nilai tertinggi dan nilai rata-rata dari masingmasing nilai pembacaan sensor yang ditunjukan oleh tabel 4.3. Nilai tertinggi dan rata-rata secara berurut yang didapat adalah putaran mesin $=2.453 \mathrm{rpm}$ dan $1.066 \mathrm{rpm}$, kecepatan $67 \mathrm{~km} / \mathrm{jam}$ dan $11,73 \mathrm{~km} / \mathrm{jam}$, engine load $=65,08 \%$ dan $32,51 \%$, temperatur $=79{ }^{\circ} \mathrm{C}$ dan $71,66{ }^{\circ} \mathrm{C}$.

Tabel IV

History data pelanggaran per interval waktu

\begin{tabular}{llllll}
\hline No & $\begin{array}{l}\text { Mesin } \\
(\mathbf{R P M})\end{array}$ & $\begin{array}{l}\text { Kec. } \\
(\mathbf{K M} / \mathbf{J a} \\
\mathbf{m})\end{array}$ & $\begin{array}{l}\text { Engine } \\
\text { Load }(\%)\end{array}$ & $\begin{array}{l}\text { Temp. } \\
(\mathbf{C e l c i u} \\
\mathbf{s})\end{array}$ & Date \\
\hline $\mathbf{1}$ & 2722 & 75 & 63.53 & 79 & $\begin{array}{l}8-11-2016 \\
17: 20\end{array}$ \\
\hline $\mathbf{2}$ & 2562 & 71 & 58.04 & 78 & $\begin{array}{l}8-11-2016 \\
17: 24\end{array}$ \\
\hline $\mathbf{3}$ & 2621 & 72 & 57.65 & 79 & $\begin{array}{l}8-11-2016 \\
17: 26\end{array}$ \\
\hline $\mathbf{4}$ & 2566 & 28 & 55.29 & 78 & $\begin{array}{l}8-11-2016 \\
17: 33\end{array}$ \\
\hline $\mathbf{5}$ & 2613 & 30 & 40.78 & 77 & $\begin{array}{l}8-11-2016 \\
17: 36\end{array}$ \\
\hline $\mathbf{6}$ & 1730 & 25 & 81.57 & 80 & $\begin{array}{l}8-11-2016 \\
17: 55\end{array}$ \\
\hline $\mathbf{7}$ & 2558 & 39 & 56.47 & 79 & $\begin{array}{l}8-11-2016 \\
17: 58\end{array}$ \\
\hline $\mathbf{8}$ & 1488 & 36 & 86.67 & 80 & $\begin{array}{l}8-11-2016 \\
17: 59\end{array}$ \\
& & & & & \\
\hline
\end{tabular}

Tabel IV merupakan history data pelanggaran per interval waktu. Data yang dimunculkan adalah semua pelanggaran yang terjadi pada interval tersebut. Jumlah pelanggaran yang terjadi adalah sebanyak 7 pelanggaran.

Pengujian per hari

Pengujian dilakukan dengan memilih pilihan all hours pada halaman pemilihan interval waktu. Artinya program akan memproses semua data pada tanggal tersebut. Hasil pengujiannya adalah sebagai berikut

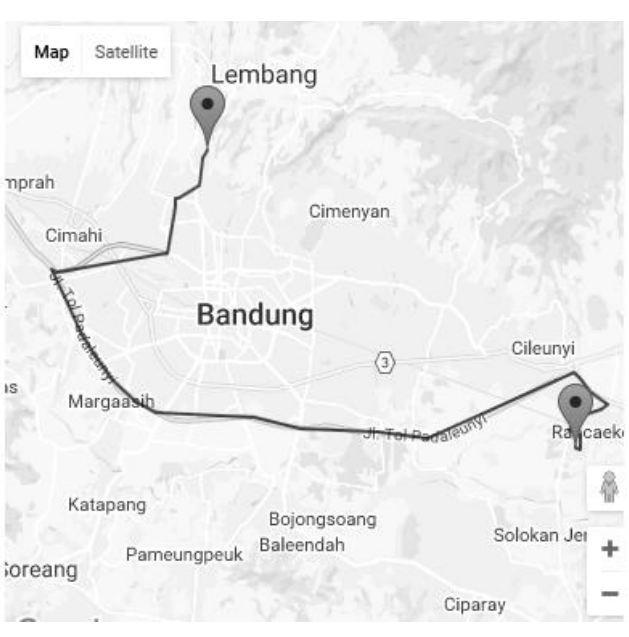

Gbr. 8 History map per hari

Gbr. 8 merupakan history maps pada tanggal 11 Agustus 2016. Penanda menunjukan posisi awal dan posisi akhir dari mobil.

Tabel V

History data OBD II per hari

\begin{tabular}{|c|c|c|c|c|c|}
\hline $\begin{array}{l}\text { Mesin } \\
(\text { RPM) }\end{array}$ & $\begin{array}{l}\text { Kec. } \\
(\mathrm{Km} / \mathrm{Jam} \\
\text { ) }\end{array}$ & $\begin{array}{l}\text { Engine } \\
\text { Load (\%) }\end{array}$ & $\begin{array}{l}\text { Temp. } \\
\text { (Celciu } \\
\text { s) }\end{array}$ & Date & Time \\
\hline 1255.50 & 33.00 & 33.00 & 58.83 & $\begin{array}{l}11 \text { Aug } \\
2016\end{array}$ & $12: 13$ \\
\hline 1800.00 & 40.00 & 20.00 & 70.00 & $\begin{array}{l}11 \text { Aug } \\
2016\end{array}$ & $13: 46$ \\
\hline 1226.50 & 33.50 & 32.94 & 39.50 & $\begin{array}{l}11 \text { Aug } \\
2016\end{array}$ & $14: 15$ \\
\hline 1055.99 & 8.43 & 32.91 & 75.92 & $\begin{array}{l}11 \text { Aug } \\
2016\end{array}$ & $16: 17$ \\
\hline 1691.85 & 29.65 & 46.91 & 78.87 & $\begin{array}{l}11 \text { Aug } \\
2016\end{array}$ & $17: 07$ \\
\hline 716.50 & 2.00 & 33.73 & 82.00 & $\begin{array}{l}11 \text { Aug } \\
2016\end{array}$ & 18:06 \\
\hline
\end{tabular}

Tabel V

Analisis data OBD II per hari

\begin{tabular}{lllll}
\hline & $\begin{array}{l}\text { Mesin } \\
(\mathbf{R p m})\end{array}$ & $\begin{array}{l}\text { Kecepatan } \\
(\mathbf{K m} / \mathbf{J a m})\end{array}$ & $\begin{array}{l}\text { Engine } \\
\text { Load }(\%)\end{array}$ & $\begin{array}{l}\text { Temp. } \\
(\text { Celcius })\end{array}$ \\
\hline $\begin{array}{l}\text { Nilai } \\
\text { Tertinggi }\end{array}$ & 1800.00 & 40.00 & 46.91 & 82.00 \\
\hline $\begin{array}{l}\text { Nilai } \\
\text { Rata-Rata }\end{array}$ & 1106.62 & 20.94 & 28.50 & 57.87 \\
\hline
\end{tabular}

Tabel V merupakan history data dari pembacaan data OBD II pada tanggal yang sama. Data yang ditampilkan merupakan nilai rata-rata setiap jam. Ditampilkan pula data nilai tertinggi dan nilai rata-rata di tanggal tersebut yang ditunjukan oleh Tabel VI. Nilai tertinggi dan rata-rata secara berurut yang didapat adalah putaran mesin $=1.800 \mathrm{rpm}$ dan1.106,62 rpm, kecepatan $40 \mathrm{~km} / \mathrm{jam}$ dan $20,94 \mathrm{~km} / \mathrm{jam}$, engine load $=46,91 \%$ dan $28,50 \%$, temperatur $=$ $82{ }^{\circ} \mathrm{C}$ dan $57,87^{\circ} \mathrm{C}$. 
Tabel VI

History data pelanggaran PER HARI

Error Rate Driving: 5,20 \%

\begin{tabular}{llllll}
\hline No & $\begin{array}{l}\text { Mesin } \\
(\mathbf{r p m})\end{array}$ & $\begin{array}{l}\text { Kec. } \\
(\mathbf{k m} / \mathbf{j a m} \\
)\end{array}$ & $\begin{array}{l}\text { Engine } \\
\text { Load } \\
(\boldsymbol{\%})\end{array}$ & $\begin{array}{l}\text { Temp. } \\
(\text { Celciu } \\
\mathbf{s})\end{array}$ & Date \\
\hline $\mathbf{1}$ & 2722 & 75 & 63.53 & 79 & $\begin{array}{l}8-11-2016 \\
17: 20\end{array}$ \\
\hline $\mathbf{2}$ & 2562 & 71 & 58.04 & 78 & $\begin{array}{l}8-11-2016 \\
17: 24\end{array}$ \\
\hline $\mathbf{3}$ & 2621 & 72 & 57.65 & 79 & $\begin{array}{l}8-11-2016 \\
17: 26\end{array}$ \\
\hline $\mathbf{4}$ & 2566 & 28 & 55.29 & 78 & $\begin{array}{l}8-11-2016 \\
17: 33\end{array}$ \\
\hline $\mathbf{5}$ & 2613 & 30 & 40.78 & 77 & $\begin{array}{l}8-11-2016 \\
17: 36\end{array}$ \\
\hline $\mathbf{6}$ & 1730 & 25 & 81.57 & 80 & $\begin{array}{l}8-11-2016 \\
17: 55\end{array}$ \\
\hline $\mathbf{7}$ & 2558 & 39 & 56.47 & 79 & $8-11-2016$ \\
& & & & & $17: 58$ \\
\hline $\mathbf{8}$ & 1488 & 36 & 86.67 & 80 & $\begin{array}{l}8-11- \\
2016 \\
17: 59\end{array}$ \\
\hline & & & & & \\
\hline
\end{tabular}

Tabel VII merupakan history data pelanggaran. Data yang dimunculkan adalah semua pelanggaran yang terjadi pada tanggal tersebut. Ditampilkan pula analisis data error rate driving yang menunjukan tingkat kesalahan dari cara berkendara. Tingkat kesalahan mengemudi yang dihasilkan yaitu sebesar 5,20\% dengan jumlah total pelanggaran sebanyak 9 pelanggaran dari total 173 data yang masuk selama 5 jam penggunaan mobil.

\section{Analisis}

Pada proses pengambilan data OBD II oleh raspberry, data berhasil diambil dengan baik sesuai pemilihan data yang diperlukan. Data tersebu-t adalah rpm, engine load, temperatur dan kecepatan. Data masuk ke file Log dengan interval waktu rata-rata per satu detik. Data masuk dengan konstan dan relatif tidak ada interval waktu yang menonjol antar setiap pengiriman data. Data tersebut siap dikirim ke raspberry melalui program supervisi_drisal.py.

Pada proses pengiriman data oleh raspberry ke database yang disediakan di web server, data dikirim setiap 30 detik menggunakan koneksi internet. Pada proses ini sangat dipengaruhi oleh kestabilan koneksi internet. Dapat dilihat dari interval pengiriman setiap data yang relatif tidak pernah tepat 30 detik. Akan tetapi untuk keadaan koneksi inernet yang stabil, data yang dikirim relatif tidak memiliki delay yang berlebihan.

Selanjutnya pada proses pengiriman koordinat yang dilakukan oleh smartphone dilakukan setiap interval 1 menit. Proses ini juga sangat dipengaruhi oleh kestabilan koneksi internet. Bahkan dari beberapa kali percobaan bisa dikatakan koneksi internet pada modem lebih stabil dibanding koneksi internet yang digunakan smartphone untuk provider yang sama. Pada percobaan yang dilakukan terjadi beberapa kali mengalami delay pengiriman data yang mencapai lebih dari 2 menit. Setelah diteliti, keadaan tersebut terjadi saat mobil berada di daerah yang kurang mendapatkan pasokan sinyal dari provider yang digunakan.
Dari hasil pengujian program monitoring, dapat dilihat bahwa program berjalan sesuai harapan. Koordinat pada map langsung ter-update ketika ada data baru yang masuk ke database web. Koordinat yang ditampilkan pada map adalah koordinat paling akhir yang masuk ke database web. Hal ini menunjukan bahwa hasil dari program monitoring berjalan sesuai rencana.

Untuk program reporting dilakukan beberapa pengujian interval waktu yaitu per jam dan per hari. Yang pertama adalah program reporting map. Program reporting map berjalan dengan baik sesuai dengan interval waktu yang dipilih. Program map berhasil menampilkan rute perjalanan yang dilalui mobil sesuai waktu yang telah ditentukan.

Yang kedua adalah Yang kedua adalah program reporting data OBD II. Untuk program reporting data OBD II per jam dapat dilihat bahwa program berhasil menampilkan semua data yang masuk ke database untuk interval waktu yang dipilih.

Sementara program reporting data OBD II per hari berhasil menampilkan nilai rata-rata dari setiap indikator penilaian yang masuk untuk untuk setiap jam. Kedua program report berjalan dengan baik sesuai dengan pemilihan interval waktu yang diinginkan oleh pemilik rental.

Yang ketiga adalah program pelanggaran. Program pelanggaran ini berhasil menampilkan pelanggaran-pelanggaran yang telah dilakukan oleh pengemudi baik itu per jam atau per hari. Dari hasil pengujian dapat dilihat bahwa program ini berhasil memunculkan nilai dari tingkat kesalahan pengemudi mobil rental. Dimana nilai tersebut didapat dari presentase jumlah pelanggaran terhadap jumlah keseluruhan data yang masuk sesuai pemilihan interval waktu.

Setelah dilakukan perhitungan data secara manual, data yang masuk pada tanggal 11 Agustus 2016 adalah sejumlah 173 data dengan banyaknya pelanggaran sebanyak 9 pelanggaran. Jika kita masukan data ini kepada persamaan pada Gbr. 2.1, maka didapat hasil yang sama untuk tingkat kesalahan mengemudi seperti pada program web yaitu sebesar 5,20\%.

Yang keempat adalah program reporting all data. Program tersebut menampilkan keseluruhan data dari mulai history map, history data dan driving error rate. Dari hasil pengujian tidak ditemukan error dan program berhasil menampilkan semua data sesuai pemilihan interval waktu yang ditentukan.

\section{KESIMPULAN}

Berdasarkan hasil penelitian yang dilakukan, dapat ditarik kesimpulan sebagai berikut.

1. Smartphone berhasil mengirimkan data lokasi ke web server dengan baik. Data lokasi berhasil dikirim setiap menit meskipun beberapa kali terjadi delay yang disebabkan oleh kualitas internet.

2. Raspberry berhasil mengambil data dari OBD II dan mengirimkan data tersebut ke web server. Data dari OBD II berhasil dikirimkan setiap 30 detik meskipun terdapat beberapa data yang mengalami delay pengiriman yang dipengaruhi oleh kualitas internet. Dari uji coba selama kurang lebih 5 jam, raspberry berhasil mengirimkan data sebanyak 173 data.

3. Program Monitoring dapat menampilkan lokasi terbaru sesuai data lokasi terbaru yang ada di database.

4. Program Reporting dapat melakukan pengolahan keseluruhan data OBD II yang masuk ke database. 
Program berhasil menampilkan report data per interval jam maupun per hari. Program juga berhasil melakukan perhitungan jumlah data yang masuk dan jumlah pelanggaran yang terjadi untuk kemudian melakukan perhitungan nilai driving error rate.

Data pelanggaran yang tercatat adalah sebanyak 9 pelanggaran dari total 173 data yang ada. Oleh karena itu tingkat kesalahan mengemudi yang didapat adalah sebesar $5,20 \%$. Nilai ini relatif cukup besar, akan tetapi penilaian akhir diserahkan kepada pemilik rental apakah pengguna jasa masih layak atau tidak untuk diberikan kepercayaan sebagai pengguna jasa kembali karena sistem ini hanya bersifat sebagai laporan yang memberikan gambaran perilaku mengemudi.

\section{REFERENCES}

[1] Elvik, R. (2009). The Power Model of the relationship between speed and road safety: update and new analyses. TØI Report 1034/2009. Institute of Transport Economics TØI, Oslo.

[2] Nilsson, G. (2004). Traffic safety dimensions and the power model to describe the effect of speed on safety. Lund Bulletin 221. Lund Institute of Technology, Lund.

[3] Rosén, E., Stigson, H. \& Sander, U. (2011). Literature review of pedestrian fatality risk as a function of car impact speed. In: Accident Analysis and Prevention, vol. 43, nr. 1, p. 25-33.

[4] Asthon, Kevin. That 'Internet of Things' Thing. RFID Journal, 2009.

[5] Sim, Alex Xandra Albert and Sitohang, Benhard. OBDII standard car engine diagnostic software development. International Conference on Data and Software Engineering (ICODSE). 2014.

[6] E/E Diagnostics Test Modes SAEJ1979/ISO 15031-5, Vehicle E/E System Diagnostic Standards Committee, Society of Automotive Engineers.

[7] Yay, Emre and Madrid, Natividad Martinez. A New Driving System Towards Energy-Efficient and Safe Driving Behaviour. 10th International Workshop on Intelligent Solutions in Embedded Systems, 2012.

[8] Mulia, Samuel Adelwin., et al. VISCar : Aplikasi Internet of Things dalam Sistem Monitoring untuk Peningkatan Efisiensi Penggunaan Bahan Bakar bagi Jasa Rental Mobil. ITB, 2016. Journal Article from a Full Text Database

[9] E. Husni, G. B. Hertantyo, D. W. Wicaksono, F. C. Hasibuan, A. U. Rahayu and M. A. Triawan, "Applied Internet of Things (IoT): Car monitoring system using IBM BlueMix," 2016 International Seminar on Intelligent Technology and Its Applications (ISITIA), Lombok, 2016, pp. 417-422, doi: 10.1109/ISITIA.2016.7828696.

[10] Shete, Rohini and Agrawal, Sushma, IoT based urban climate monitoring using Raspberry Pi, International Conference on Communication and Signal Processing (ICCSP), 2016

[11] Chan, Eddie C. L, Baciu, George, Introduction of Global Positioning System, Wiley-IEEE Press, vol. 1, pp. 121 136, 2012.

\section{BIOGRAFI PENULIS}

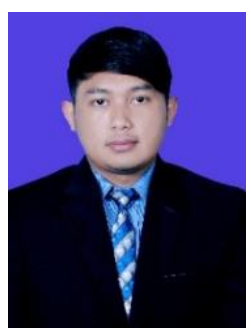

Andri Ulus Rahayu, lahir di Bandung pada tanggal 03 April 1989. Saat ini bertugas sebagai dosen di Jurusan Teknik Elektro, Universitas Siliwangi. Bidang penelitian yang ditekuni saat ini adalah bidang Sistem kendali berbasiskan teknologi komputer. 